\title{
The Gaudí floor tile: memory, trajectory and identity in Catalan industrial design
}

What are the reasons that led to Gaudi's hexagonal tile becoming a reference point in industrial design with international dissemination? Its origins as an encaustic tile lie in the era of splendour of Catalan Modernisme, in the early zoth century. It was recognised as a solution for modernity in the 1960 s, with the process of emerging design culture in Catalonia, which prompted its transformation into an emblematic paving tile for Barcelona's public spaces. Finally, in the late 1990s, the tile was restored to its original format, acquiring the connotation of urban icon. Since it first appeared, Gaudi's famous tile has not only demonstrated its versatile nature and easy adaptation to changes of use, it has also played a fundamental role in constructing the cultural, urban and touristic identity of the city of Barcelona. These two factors already form part of the object's memory and are responsible for its singularity. The analysis proposed here places emphasis on the processes that, from the start of its production, distinguished the tile as a true object of industrial design, thanks to the innovative correlation it established between artistic creativity, technical research and business strategy, together with the evolution of demand and cultural changes.

keywords encaustic tile, exterior paving, catalan design, Gaudí, Escofet

\section{Introduction. From flooring to urban icon}

To discuss Antoni Gaudís mosaic floor tile as used at Casa Milà, "la Pedrera", means unanimously accepting two apparently indissociable aspects: it is acclaimed as the finest example of Catalan industrial design in its origins, while simultaneously it is one of the elements most identified with the city of Barcelona. These two aspects converge in a single object but were produced over a long period of time with two main milestones, i.e., the creation of the original design, in around 1904, and its re-introduction into Barcelona's public space, from 1997 onwards. It took nearly one hundred years to undergo this transformation, from compacted cement mortar floor tile with a singular design to urban icon, recognised internationally and found in a host of objects designed for the tourist market. It is interesting to analyse what fundamental factors were involved in a trajectory that follows a route of development from industrial design rooted in certain materials and technical processes, to become an element that is the object of aesthetic appreciation and divorced from its initial function, with a notable component of urban and cultural identity.

The success of Gaudi's floor tile can be interpreted through the methodological focus of the "the cultural biography of things", defended by Lees-Maffei, who cites a 1986 essay by Igor Kopytoff. There are three key points in the evolution of Gaudi's mosaic floor tile, from industrial design to cultural and tourist icon, which we term, respectively, memory, 
trajectory and identity. In the memory lies the genesis of the design, the genius of the artist who created it, the technical and formal values, as well as its influence on the renewal of interior floorings. In short, the tandem established between Gaudí and the tile's original producer, the Escofet Company, a circumstance that from the start led to it being ascribed the attribute of industrial design.

The trajectory is endorsed by the conversion of Gaudís tile into an outdoor paving tile for the public space of Barcelona. Or to refer to it by its Catalan name, a panot for sidewalks. Several decades after the architect's death, the urban redevelopment of Passeig de Gràcia in 1976 afforded Escofet the opportunity to produce the piece once more using a new technical procedure, Vibrazolit Relieve, or vibro-compacted concrete. The mosaic floor tile, reinterpreted, thus remained firmly linked to Escofet's corporate heritage assets, but it now bore implicit some of the most relevant aspects of design culture in Barcelona: firstly, the urban reform of Passeig de Gràcia emerged in a pioneering operation for the improvement of the city's public spaces where the design factor formed an indissociable part of projects of greater scope; secondly, the recovery of the Gaudí tile showed how an object from the past could continue being designed by craftsmen of the present.

Various authors have pointed out that the identity and quality of Spanish design is based on its connection with local culture. In the Catalan case, the continuity existing between Modernisme and the most contemporary design is, certainly, a differentiating element. It had an initial high point in 1962, when the Gaudí tile was awarded the Delta d'Or Prize by the newly created ADI-FAD (Association of Industrial Design for Fostering Decorative Arts). With the prize, local objects were vindicated, as Narotzky affirms, as design classics, in a stage of Catalan society where design became a pre-eminent factor in the renewal of cultural life. In addition, it secured Gaudís tile as the founding object of Catalan, and by extension, of Spanish design.

The last step in this trajectory was when Gaudi's panot acquired the status of global symbol of the Catalan capital's urban and cosmopolitan culture. A new remodelling of Passeig de Gràcia, in 1997, within the context of the renowned Barcelona Model, which was implemented from the 1980 s and geared towards attaining a quality public space, led Escofet's technical office to restore the piece in line with its original characteristics. The city has been phasing in the new panot in successive stages for over fifteen years now and, perhaps it is important to observe that its spread has been closely linked to the consolidation of Barcelona as a world-class tourist destination and to the specialisation of Passeig de Gràcia as the highest quality shopping artery in the city.

In this context, the Gaudí tile plays a leading role in the construction of the cultural imaginary of visitors to Barcelona. In the diversity of tourist memento products inspired by the original design, its function is confirmed as a mediator for evoking various symbolic reference points, including the demonstration of the importance of Catalan design in achieving tourist souvenirs of quality.

All this baggage shapes "the cultural biography of the thing" and reinforces the currency of Gaudi's work, both in his architectural creations and in his design of useable objects. None of these has achieved the level of popularity enjoyed by his mosaic tile, and, at the same time, been subject to so many transformations based on the original object. It requires, precisely, a detailed approach to its origins to allow an in-depth understanding of why it became a work of reference in Catalan industrial design. 


\section{Gaudí and Escofet: creative process and business strategy}

As has been repeatedly published, Gaudí originally designed his tile for Casa Batlló, built between 1904 and 1906, but ended up using it in Casa Milà, "la Pedrera", built from 1906 onwards; both buildings are located on Passeig de Gràcia. The marine motifs that Gaudí chose were more attuned with the iconographic programme of Casa Batlló, but that was no impediment to his using it in the flooring of the building considered as the pinnacle of his creation in domestic architecture (Fig. 1).

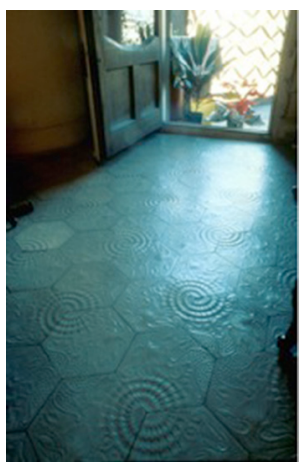

Production was the responsibility of what was then "E.F. Escofet y Cia.", a company which, since it was founded in 1886, had produced encaustic tiles and other elements obtained from compressed cement. In recent times, Escofet has been considered a pioneering reference point within the industrial design field, for having taken a decisive step in the process leading from the industrial arts towards a culture of modern design. The most evident reason for this consideration lies in the company's skill in adapting a kind of production that was still relatively hand-crafted, such as that of the encaustic tile, to an industrialised infrastructure, added to its eagerness for opening up towards an international market.

This is quite a remarkable circumstance within the particular context of Catalan Modernisme. Careful analysis of events during the last third of the 19th century in Barcelona makes it apparent that the Escofet option could have been excluded from the arts renewal movement and yet, in contrast, it formed an important part of it. Modernisme symbolised the great period of recovery for the decorative arts that had a strong component of reviving ancient artistic trades. The prime movers of this recovery followed craft processes, largely to find solutions for works that were unique and often exclusive. The decorative arts, therefore, remained far removed from the patterns that increasingly distinguished industrial design, as their most valuable manifestations were to be found in projects for the interior design of large houses for the emerging urban middle class.

In contrast, from the start Escofet built up a confirmed reputation as the most important encaustic tile company. So, what were the factors playing a role in this reputation? The starting point was the industrial substrate, and mass production for the construction sector. However, it combined these with a business strategy that integrated design as a key function in its industrial process that provided added value, i.e., concern with the aesthetic factor based on the cultural patterns of renewal of the arts of the time.
Figure 1.

Gaudí floor mosaic tiles at La Pedrera. 1906-1910 (CEscofet, 1886 S.A.) 
theme 3

identity

Figure 2.

Metallic mould of the Gaudí mosaic tile (@) Escofet, 1886 S.A.) strand 1

design process and pratice

In turn-of-the-century Barcelona, a process of change in artistic sensitivity was taking place based on a reinterpretation of the mediaeval past and on the entry of European currents. A formal language for objects designed to distinguish an upwardly-rising middle-class, consisting of industrialists and urban property owners who were starting to colonise the new city in line with engineer Ildefons Cerdà's Plan for the Eixample area. In this construction of cultural identity, between refinement and the desire for distinction, a company such as Escofet was undoubtedly the most successful example of a strategy aimed at achieving industrial design.

An essential element of this strategy was to find a favourable market position for the consumption of a new product in the construction field such as the encaustic tile at that time. It was necessary to compete with traditional floorings, those occupying the middle and the high end of demand alike. This was achieved by expanding the potential market area through product diversification while taking advantage of the technical possibilities offered by the material for incorporating new designs. The aim was to create a product that covered a broad market segment and fulfilled the demands of important projects without overlooking, however, that the business's base was the large-scale demand for building materials for residential architecture.

This is why Escofet requested collaboration from the artistic world, and left a record of this collaboration through the signing of the tile designs published in its commercial catalogues. Auteur productions served to strengthen the company's customer base. They also served to create some of the best productions of Catalan Modernisme in the sphere of the industrial arts, such as the company's catalogue from the year 1900, designed for its presentation at the Exposition Universelle in Paris that same year.

From this perspective, Gaudís tile is the perfect result of the tandem formed by the architect and Escofet. Comparison of the piece with mosaic tiles produced at the same time allows us to confirm its decidedly valuable role in terms of renewal within the flooring field. To begin with, it is a hexagonal-shaped piece in bas-relief, whereas all encaustic tiles were produced as square-shaped pieces with a standard measurement of $20 \times 20 \mathrm{~cm}$ and a smooth surface. Gaudís flooring was composed of a single monochrome piece joined to form continuous flooring rather than the traditional composition imitating a chromatic rug with diverse formal motifs, centred in the room.

As has been recognised, it adapted well to the irregular floor surfaces of Gaudís buildings. The composition obtained is based on a tile with a single design but presenting three different, decentralised marine-life motifs, arranged at three alternate angles. Thus, quite a number of tiles are needed to obtain the complete form of the snail, the starfish and the seaweed, which compose an uninterrupted sequence of the theme in a dynamic way (Fig. 2).

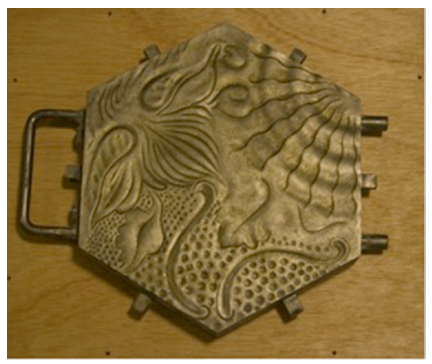


We must question what the architect's references were to break with the convention of encaustic tiles. Firstly, it must be remembered that Gaudís hexagonal tile was designed for the service rooms at La Pedrera. The state rooms had floors of parquet and natural stone, following the tradition in important houses. This favoured Gaudí adapting the arrangement usually suited to simple encaustic tile models destined for functional areas in houses, to a single model that spread in a continuum along the floors of the spaces.

However, while these tiles could be hexagonal in shape they would never feature relief, as exposed-face finishes were reserved for outdoor paving. And here lies Gaudís other reference for producing the sinuous surface of his mosaic tile floor. A likely hypothesis is that the architect's tile is a reinterpretation of the outside tiles designed for pavements, the famous panots, uncoloured Portland cement tiles with motifs in relief for their antislip function. In Barcelona, panots were the material par excellence for developing its sidewalks. Their origin lies in tiles suited for outdoor yards and deposits, from the last third of the 19th century. In 1906, Barcelona City Council decided to adopt them as paving tiles for the sidewalks of the most important streets in the Eixample area and published a set of models. Several of these, years later, would become the official models for the entire city (Fig. 3).

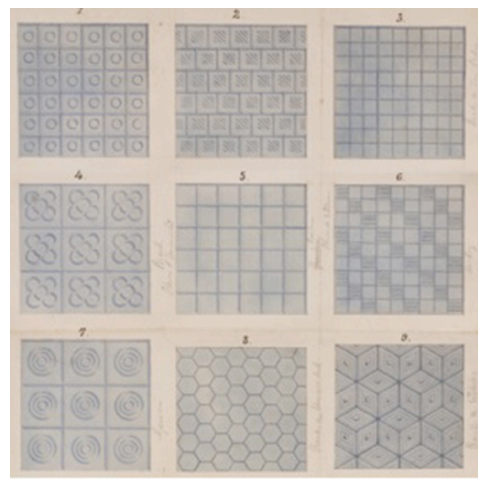

Figure 3 . Barcelona City Council's panot models for street pavements. 1906-1907 (๔) Contemporary Municipal Archive of Barcelona)

This was how one of the most charismatic products of Barcelona's urban development from the early 2oth century became consolidated. Today, the well-known $20 \times 20 \mathrm{~cm}$ rose panot is also an urban icon ingrained in Barcelona's identity and it competes, alongside the Gaudí panot, - flower panot - as one of the most emblematic tourist products that the city offers its visitors.

\section{Conclusion}

With his creation, Gaudí showed how continuous flooring formed by an identical and monochrome hexagonal tile could become a viable alternative to the encaustic tile tradition. It was his recourse to relief that allowed him to introduce the formal solution without having to resort to different colours and models. He opened the way to new approaches to flooring in his work on completing interior spaces that other tile designers followed. The models with polygonal formats adapted well to the taste for decorative simplification that became fashionable from the second decade of the 2oth century onwards for the floors of the main rooms of residences. 
In conclusion, the hexagonal tile of La Pedrera was inspired by the encaustic tiles of lower added value and by a piece that above all was functional, such as the panot. The technical and formal simplicity that they contributed enabled Gaudí to offer an industrial design treatment of great singularity that, evidently, the panots did not have.

We are looking at a creative result that, as in so many other creative processes that took place in the first decades of the zoth century, searched outside of the fine arts and formal conventions for sources of inspiration to obtain singular objects for renewal. With our architect, nature is an essential factor but so is structural and functional research into achieving new spaces and volumes. This synthesis makes the Gaudífloor tile a perfect example of the passage from industrial art to industrial design in the early 20 th century, with proven validity up to the present day.

\section{References}

Calvera, Anna 'La formació del mercat del disseny a Barcelona: significació del Modernisme català en la història local de disseny', Coup de fouet. International Congress, Barcelona, 26-29 June, 2013, Available: http://www.artnouveau.eu/ca/congress_ mainstrands.php?strand=5, [27 Des 2013].

Capella, J. (ed.) (2005) 300\% Spanish Design. Barcelona: Electa, Madrid: Sociedad Estatal para Exposiciones Internacionales.

Cronofad. Cronologia del Foment de les Arts i del Disseny. Available: http://www.ub.edu/ gracmon/docs/cronofad/ [30 june 2014].

Esparza, D. (2010) El modelo Barcelona de espacio público y diseño urbano: La configuración del suelo y de una imagen de ciudad, Master's degree thesis, University of Barcelona, Faculty of Fine Arts, Available: http://hdl.handle.net/2445/14802, [2 Jan 2014]. Lees-Maffei, G. (2009) 'The Production-Consumption-Mediation Paradigm', Journal of Design History, vol. 22, no. 4, pp. 351-376, Available: doi: 10.1093/jdh/eppo31, [15 Mar 2014]. Navas, T. (1986) La casa Escofet de mosaic hidràulic, 1886-1936, Degree thesis. Faculty of Geography and History. University of Barcelona (unpublished).

Narotzky, V. (2000) 'A different and new refinement design in Barcelona, 19601990', Journal of Design History, vol. 13, no.3, pp. 227-243, Available: doi: 10.1093/ jdh/13.3.227, [3 Jan 2014]. 